\title{
Tourism Demand Analysis Using Probabilistic Travel Model: A Study In Pokhara
}

\author{
Dila Ram Bhandari \\ Lecturer, Nepal Commerce Campus
}

\begin{abstract}
Tourism is now one of the largest industries in the world that has developed alongside the fascinating concept of eco-tourism. Nepal Tourism Policy 2009 identifies tourism sector as an important vehicle for economic and social development. Revenue from tourism sector is observed from foreign currency exchange made by tourists and tourism industries as proxy of income. According to Tourism Towards 2030, the number of international tourist arrivals worldwide is expected to increase by an average of 3.3\% a year over the period 2010 to 2030. At the projected rate of growth, international tourist arrivals worldwide are expected to reach 1.4 billion by 2020, and 1.8 billion by the year 2030. Nepal aims to transform its tourism sector into one of the largest foreign exchange earners in 2016 by attracting 2.5 million high spending tourists. Tourism was ranked as the fifth largest source of foreign exchange earnings in 2012 and third largest in 2013 contributing 5.2 percent to total foreign earnings of the country. This study shows the tourism infrastructure as well as seasonal arrival of tourists in Nepal and to develop the probabilistic travel model on the basis of tourist perception which will help the tourism department for the further economic development of the area. $R$-Studio based on data from the sample period from 2008 to 2016. The formula presented in this study can be used by policy makers to calculate future foreign exchange earnings, employment, arrivals and prices related to tourism in Nepal.
\end{abstract}

Key Words: Eco-tourism, command area, tourist attractions, probabilistic travel model

JEL codes: C22, E01, F43, L83

\section{INTRODUCTION}

Tourism is the largest industry in Nepal and its largest source of foreign exchange and revenue. Possessing eight of the ten highest mountains in the world, Nepal is the country of the Mount Everest, the highest mountain peak in the world, and the Birthplace of Gautama Buddha-Lumbini. Nepal is a hotspot destination for mountaineers, rock climbers and people seeking adventure. Tourism sector of Nepal is managed with partnership of Government, private sector, households, professionals and NGOs. Tourism industries play pivotal roles in tourist service, service management, increasing revenue. The total contribution of Travel \& Tourism to GDP was 6.5\% of GDP in 2016, and is forecast to rise by $6.2 \%$ in 2017 . The direct contribution of Travel \& Tourism to GDP in 2016 was $3.6 \%$ of GDP. This primarily reflects the economic activity generated by industries such as hotels, travel agents, airlines and other passenger transportation services.

Pokhara is called as a piece of heaven in the world where there is tourist 
attraction in the Pokhara, Nepal. There are many beautiful and interesting places to visit in Nepal, outside the Kathmandu Valley. Pokhara valley is the 'Jewel of the mid-west', second major tourist sport in Nepal but the favorite of tourists from around the globe. As many as 729,550 number of foreign tourists visited Nepal in 2016. The number of foreign tourists visiting Nepal in 2016 increased by $24 \%$ as compared to 2015 , according to the Department of Immigration. Indian tourists top the list of tourists visiting the Himalayan nation to China and Sri Lanka respectively. A total of 118,249 Indian tourists visited Nepal via air route while, 23,452 number of Chinese tourists out of 1,04,005 entered the nation via Rasuwa. Likewise, 57,521 tourists from Sri Lanka, 53,645 from US, 46,295 from UK, 26,722 from Thailand, 25,769 from Myanmar, 25,507 from Australia, 25,171 from South Korea, 23,812 from Germany visited Nepal last year, according to the Department of Immigration.

There is plenty of academic literature relating to tourism demand forecasting. Among many tourism forecasting models, the generally used are the traditional quantitative and qualitative research methods, such as the Delphi method, the life cycle method, the econometric method, the space gravity model, and the time sequence method, etc.

\section{RESEARCH OBJECTIVES}

The following objectives have been set for the study:

- To assess the tourism infrastructure in the Pokhara,

- To find out the nature of seasonal arrival of tourists in Pokhara and

- To develop the probabilistic travel model on the basis of tourist perception.

\section{LITERATURE REVIEW}

According to the World Tourism Organization (UNWTO, 2014), international tourist arrivals grew by $5 \%$ during the year 2014. Strongest growth was reported in the Americas (+8 percent) followed by Asia, the Pacific (+5 percent) and Europe (+4 percent). Among the South Asian countries, Nepal maintained a soiled 27 percent growth in 2013 followed by Maldives (17 percent). India, which is the largest tourist destination in South Asia, managed to have a 4 percent growth (UNWTO, 2014). Tourism was the 3rd largest foreign exchange earner for the country in 2013. Tourist earnings have increased over the past, and the current figure shows over US $\$ 1.7$ billion of foreign exchange earnings to Nepal in 2013. UNWTO strives to maximize tourism's contribution to poverty reduction and increase awareness on the sector's development potential. Over the decades, tourism has experienced continued growth and deepening diversification to become one of the fastest growing economic sectors in the world. These dynamics have turned tourism into a key driver for socio-economic progress. Tourism has become one of the major players in international commerce and represents at the same time one of the main income sources for many developing countries like Nepal.

There is bidirectional causality between tourism and economic growth according to some empirical evidence, however the question of which causes which one is still inconclusive. Tourism expenditures generate income to the host economy and stimulate the investment necessary to finance growth in other economic sectors. Tourism is one of the top five export categories for as many as $83 \%$ of countries and is a main source of foreign exchange earnings for at least 38\% of countries (Machel McCatty \& Prudence 
Serju, 2006). Armstrong, Daniel \& Francis, 1974 analyzed the causality of GDP, exchange rate and international tourism receipts and concluded that there is a strong Ganger causality relationship between international tourism receipts and economic growth, a strong causal relationship between exchange rate and economic growth and moderate causal relationships between economic growth and international tourism receipts and between exchange rate and international tourism receipts.

\section{RESEARCH METHODS}

The study is based on the primary data collected through the intensive field survey among the Nepali as well as Foreigner tourist in Nepal. The primary information is supplemented with secondary data whenever is needed. Distance of different tourist's attraction places from Nepal has been collected from SNT Taxi Stand of Nepal.

\subsection{Sample Design and Data Collection}

In order to make a proper questionnaire, primarily a pilot survey has been done to find out the most attractive places of the tourists came to Pokhara. With the help of pilot survey 15 places have been identified as most visited by the tourist. A Likert scale has been developed and sample has been collected through a detailed questionnaire. The tourists have been asked to give points which ranges 1 (denote lowest attractiveness) to 7 (denote highest attractiveness). The entire field survey was conducted during March-May, 2015 and collected data have been analyzed.

\subsection{Adoption of Statistical Techniques}

For the purpose of the present study both qualitative and quantitative methods have been adopted. However, in quantitative analysis both simple and standard statistical techniques have been used to infer the facts. The probabilistic travel model is structural forecasting model. the model described here is a derivation of a consumer choice model originally developed by Luce (1959) and applied to recreational travel.

- Primarily utility of tourism product has been measured with the help of following formula:

$$
\mathrm{Uj}=\mathrm{Sj} / \mathrm{Dij}
$$

where, $\mathrm{Uj}$ is Utility of Tourism Product Measure, $\mathrm{Sj}$ is Some Measures of Attractiveness of Destination J and Dij is Distance between Starting Point and Tourist Destination.

- After having the tourism product measure, Probabilistic Travel Attitude (1) of Tourists has been analysed with the help of following formula:

$$
\mathrm{Pij}=\mathrm{Uj} / \sum \mathrm{j}
$$

Pij is measures of Probabilistic Travel Attitude of Tourists.

\section{FINDINGS AND ANALYSIS}

In order to fulfill the objectives hotel owners, travel agent, tourists (domestic and foreign), taxi driver and local people have been selected for purposive sampling. The information regarding infrastructural facilities, probabilistic travel plan were ensured through field investigation. The entire field survey was conducted during March-May, 
2015 and collected data (Table 2) have been analysed.

Table 2. Sample size of the study

\begin{tabular}{|c|c|c|c|c|c|c|c|c|c|c|c|}
\hline \multirow{3}{*}{ Place } & \multirow{3}{*}{ 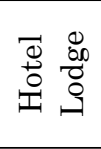 } & \multirow{3}{*}{ 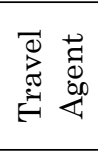 } & \multicolumn{6}{|c|}{ Tourist } & \multirow{3}{*}{ 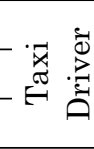 } & \multirow{3}{*}{ 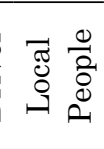 } & \multirow{3}{*}{ 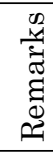 } \\
\hline & & & \multicolumn{3}{|c|}{ Foreign } & \multicolumn{3}{|c|}{ Domestic } & & & \\
\hline & & & Male & Female & Total & Male & Female & Total & & & \\
\hline Gangtok & 44 & 17 & 38 & 21 & 59 & 107 & 56 & 163 & 26 & 62 & nil \\
\hline
\end{tabular}

Source: Field Survey, January, 2015.

\subsection{Tourism Infrastructure in the Nepal}

Tourism infrastructure comprises mainly a number of good hotels, well connected to different tourist spots, a transport network, health units, marketing etc. to promote the growth and development of tourism.

Table1: Basic physical criteria for the classification of tourism accommodation

\begin{tabular}{|c|c|c|c|c|c|c|c|c|c|}
\hline \multirow{3}{*}{ Criteria } & \multicolumn{9}{|c|}{ Classification } \\
\hline & \multicolumn{4}{|c|}{ Non Star Category } & \multicolumn{5}{|c|}{ Star Category } \\
\hline & Home stay & $\mathrm{TSH}$ & Lodge & Resorts & 1 star & 2 star & 3 star & 4 star & 5 star \\
\hline $\begin{array}{l}\text { Physical } \\
\text { location }\end{array}$ & $\begin{array}{l}\text { Homely } \\
\text { environment }\end{array}$ & $\begin{array}{l}\text { Any } \\
\text { suitable } \\
\text { place }\end{array}$ & $\begin{array}{l}\text { Any } \\
\text { suitable } \\
\text { place }\end{array}$ & $\begin{array}{l}\text { Far from } \\
\text { dense } \\
\text { settlement }\end{array}$ & $\begin{array}{l}\text { Any suits } \\
\text { adequate } \\
\text { etc. }\end{array}$ & $\begin{array}{l}\text { able pla } \\
\text { space c }\end{array}$ & $\begin{array}{l}\text { ce with } \\
\text { drainage }\end{array}$ & $\begin{array}{l}\text { good vi } \\
\text { e faciliti }\end{array}$ & $\begin{array}{l}\text { iews, } \\
\text { ties }\end{array}$ \\
\hline $\begin{array}{l}\text { Room size } \\
\text { (min.) }\end{array}$ & 1 & 10 & 5 & Flexible & 15 & 20 & 30 & 50 & 70 \\
\hline $\begin{array}{l}\text { Bed size } \\
\text { (min.) }\end{array}$ & At least 2 & & & & & & & & \\
\hline $\begin{array}{l}\text { Wash } \\
\text { room(min.) }\end{array}$ & 1 & $\begin{array}{c}25 \% \\
\text { room ** }\end{array}$ & $\begin{array}{c}25 \% \\
\text { room** }\end{array}$ & $2-3$ & $\begin{array}{c}25 \% \\
\text { room }^{* * * *}\end{array}$ & all & all & all & all \\
\hline
\end{tabular}

\subsection{Seasonal Arrival of Tourists in Pokhara}

Both domestic and foreign tourists usually visit Pokhara from March to May during the summer season. The second peak season of the year is October for domestic tourists with a flow of 13.2 per cent, whereas for foreign tourists the month of October and November are the peak season for their tour to Pokhara representing a flow of 16.4 per cent and 12.2 per cent respectively.

\subsection{Probabilistic Travel Model}

Probabilistic travel model is an approach to study the nature and preferences to different tourist spots of the domestic and foreign tourists. Basically from domestic and foreign tourist perspective it has been found from the survey that, the preferences to different tourist spots are different. Therefore, the structural forecasting method is needed to interpret the factors affecting the increase or decrease of tourists. This study hope by analyzing the factors to tourists of Gangtok and its surroundings will open 


\section{Pravaha Journal-2018}

new vision to the research in this field. Both domestic and foreign tourists preferred Tsomgo Lake and Nathula Pass for its natural picturesque beauty. Every tourist enjoys the travel route to Tsomgo Lake. During April-May of every year this route is full of Rhododendron (State Flower) of different colours. Though the value of Pij becomes very low for Tsomgo Lake (2.53) and Nathula Pass (1.64), it is basically also depend on distance. According to Likert scale highest value according to preferences goes to Tsomgo Lake (6.85) and Nathula Pass (6.23).

A circuit completes the local sightseeing of 5 points or 7 points and the domestic tourist are very much enjoying this tourist spots. Rumtek Monastery, Enchey Monastery, Zoological Garden, Tibetology, Tashi View Point, Hanuman Tok, Ganesh Tok etc. are the important spots have been point out by the domestic tourist. Flower show, Directorate of Handicraft and Handloom House, Lal Market are the local sights within the Gangtok city and tourists can easily access those points by walking.

\begin{tabular}{lcccccccccccccccc}
\hline TP & PL & DF & SRKt & B.L & WPP & Musm & SR & MC & RL & HV & BT & Annp. & M & RC & NFE & PG \\
\hline Dij & 40 & 56 & 8 & 21 & 24 & 3 & 25 & 7 & 12 & 8 & 5 & 14 & 5 & 6 & 3 & 4 \\
Sj & 6.85 & 6.23 & 5.89 & 4.45 & 5.83 & 2.32 & 3.72 & 3.52 & 3.76 & 4.72 & 2.11 & 3.02 & 1.92 & 1.32 & 2.01 & 4.21 \\
Ui & 0.17 & 0.11 & 0.74 & 0.21 & 0.24 & 0.77 & 0.15 & 0.50 & 0.31 & 0.59 & 0.42 & 0.22 & 0.38 & 0.22 & 0.67 & 1.05 \\
Pij & 2.53 & 1.64 & 10.88 & 3.13 & 3.59 & 11.43 & 2.20 & 7.43 & 4.63 & 8.72 & 6.24 & 3.19 & 5.68 & 3.25 & 9.90 & 15.56 \\
\hline
\end{tabular}

\begin{tabular}{lcccccccccccccccc}
\hline TP & PL & DF & SRKt & B.L & WPP & Musm & SR & MC & RL & HV & BT & Annp. & M & RC & NFE & PG \\
\hline Dij & 40 & 56 & 8 & 21 & 24 & 3 & 25 & 7 & 12 & 8 & 5 & 14 & 5 & 6 & 3 & 4 \\
Sj & 6.85 & 6.23 & 5.89 & 4.45 & 5.83 & 2.32 & 3.72 & 3.52 & 3.76 & 4.72 & 2.11 & 3.02 & 1.92 & 1.32 & 2.01 & 4.21 \\
Ui & 0.17 & 0.11 & 0.74 & 0.21 & 0.24 & 0.77 & 0.15 & 0.50 & 0.31 & 0.59 & 0.42 & 0.22 & 0.38 & 0.22 & 0.67 & 1.05 \\
Pij & 2.53 & 1.64 & 10.88 & 3.13 & 3.59 & 11.43 & 2.20 & 7.43 & 4.63 & 8.72 & 6.24 & 3.19 & 5.68 & 3.25 & 9.90 & 15.56 \\
\hline
\end{tabular}

Source: Field survey

Note: TP-Tourist place,PL-phewa lake,SRKt-sarangkot, BL-begnas Lake, WPPworld peace pagoda, Musm-meusium,DF-devis fall, RL-rupa lake, HV-himalayan vista, Annp-Annapurna, M-Manaslu, RC-rock climbing, NFE-neight sight and entrt. PG-paragliding

\section{CONCLUSION}

Pokhara as the state capital of Sikkim has a historical background and is influenced by the traditional ethnic culture of Nepal. During the survey it has been observed 90 percent of the domestic tourists were from Kathmandu 10 percent were from other places of the country. As a result, Pokhara has now become a cosmopolitan city, which has inculcated a mixed culture in terms of language, food habits, dress etc. In such a way the state capital, Pokhara would able to maintain a sustainable growth in tourism through the process of eco-tourism without disturbing the bio-diversity in and around Pokhara.

\section{REFERENCES}

Bao, J. (1992). Application of the Gravity Model in Tourist Forecasting. Journal of Zhongshan 
University (Natural Science): 401: 133-135.

Formica, S. \& Uysul, M. (2006). Destination attractiveness based on supply and demand evaluations: an analytical framework. Journal of Travel Research; 44: 418-430.

Loving wood, P. E. \& Mitchell, L. E. (1989). Regional analysis of South Carolina tourism. Annals of Tourism research:16: .301-317.

(TERUM): 7(16): 69-85. 